\title{
Non-timber Forest Products, Their Vulnerability and Conservation in a Designated UNESCO Heritage Site of Arunanchal Pradesh, India
}

\author{
Kaushalendra K. JHA \\ Indian Institute offorest Management, Faculty of Technical Forestry, Nehru Nagar, Bhopal, MadhyaPradesh462003, India;jhakk1959@gmail.com
}

\begin{abstract}
The Apatani, non-nomadic tribe, have evolved an ecologically sustainable system of rural forestry in Ziro Valley, a proposed heritage site of UNESCO. They have been using non-timber forest products (NTFPs) grown in homestead and nearby forests for a very long period. The present study was aimed at identification of priority NTFPs and uses, their availability status and availability trend, conservation need, and sustainability interventions. Qualitative methods of research like, exploratory survey, questionnaire survey, focus group discussion, semi-structured interview of key informants, etc. were employed for data collection. The Apatani used 112 priority NTFPs for food supplement, herbal medicine, house building material and other purposes. However, on the basis of ecological importance such NTFPs were categorized as very low, low, moderate, high, and very high vulnerable species. Twenty vulnerable species like Antiitari ayi (Actinidia callosa), Biiling (Choerospondias axillaris), Henchi (Rubus niveus), Jojuru ayi (Coccinia grandis), Ngiilyang Khiiko (Centella asiatica) etc. should be conserved and seventeen not vulnerable species at this stage like, Padii hamang (Cardamine hirsute), Sankhe (Quercus griffithii), Bije (Phyllostachys manii), Hïgu hamang (Oenanthe javanica), Kiira (Quercus dealbata), etc. could be commercialized. However, a balance needed to be struck between commercialization and conservation by adopting a comprehensive policy based on scientific and traditional Apatam $i$ knowledge for harvesting and regeneration of NTFPs. Homegardening or community farming is recommended for sustainable supply of commercially important species to be domasticated.
\end{abstract}

Keywords: availability status, availability trend, conservation need, homegardening, priority NTFPs, sustainable intervention, vulnerability index

\section{Introduction}

A majority of tribal communities in Arunanchal Pradesh depend on forest resources, in the form of non-timber forest products (NTFPs), for their livelihood and daily need. One such community, the Apatani, confined to the Ziro Valley of the Lower Subansiri district, is still entirely dependent on forest resources and products for their daily requirement of food supplements (like fruits and vegetables), herbal medicines, dyes, firewood, other household and religious needs (Yakang et al., 2013). The Apatani have created one of the most intensively cultivated and ecologically sustainable economies in Ziro Valley achieved anywhere in the world (Taylor, 2009). Over the centuries, Apatani socio-cultural forms have grown in intricacy, structure and mutual interdependence, as population density, prosperity and intensity of land utilization has grown (FurerHaimendorf, 1980). They have also evolved an ecologically sustainable system of rural forestry, which not only supports their livelihood by meeting the need for food, fuelwood, timber, fodder and medicine but has also helped in protecting biodiversity (Barua and Slowik, 2000).

The Apatani are subsisting on bioresources produced in the Valley and are independent of the outside world for their need of food, medicine, housing material, etc. This self-reliance is the result of a rich traditional ecological knowledge system practiced for the maintenance of a sustainable livelihood (Barua and Slowik, 2000). Their culture, tradition, knowledge about agriculture, forest management system and conservation techniques are so unique and valued that the Valley is proposed as UNESCO heritage site (Dollo et al., 2009; Rahman, 2015; Yakang, 2015). However, increasing population, increased exposure to life outside the Valley and adoption of a modern lifestyle may influence the status of NTFPs for financial gain with an inherent risk of commercial exploitation followed by sustainability issue.

Since Apatani history developed during several centuries now is getting influenced by the spread of cosmopolitan culture (Rechlin and Varuni, 2006) with suspected impact on self-reliant traditional knowledge and practices of wild resource use, the present study was aimed at gathering information on the NTFPs and their current management practices. The focus was on the identification of priority NTFPs and uses, their availability status and trend, conservation need, and sustainability intervention.

\section{Materials and Methods}

\section{Study site}

This was an exploratory and qualitative study on collection, consumption and conservation of NTFPs in Ziro (27 33'59'N and $93^{\circ} 49^{\prime} 53^{\prime \prime E}$ ) Valley in Lower Subansiri district of 


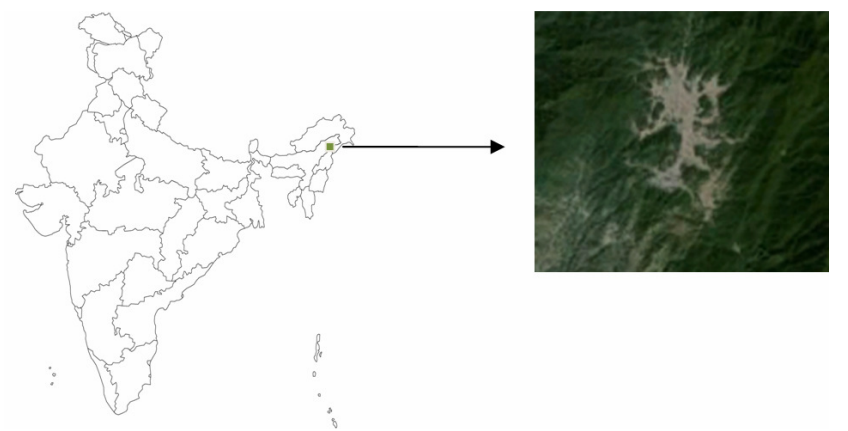

Fig. 1 shows the location of the study site and topographical features of Ziro valley (inset) in Arunanchal Pradesh, India. Courtesy

\begin{tabular}{|c|c|c|c|c|}
\hline $\begin{array}{l}\text { Abundant } \\
\text { Increase }\end{array}$ & $\begin{array}{l}\text { Abundant } \\
\text { Stable }\end{array}$ & $\begin{array}{l}\text { Abundant } \\
\text { Decrease }\end{array}$ & & \\
\hline & $\begin{array}{l}\text { Limited } \\
\text { Increase }\end{array}$ & $\begin{array}{l}\text { Limited } \\
\text { Stable }\end{array}$ & $\begin{array}{l}\text { Limited } \\
\text { Decrease }\end{array}$ & \\
\hline & & $\begin{array}{l}\text { Scarce } \\
\text { Increase }\end{array}$ & $\begin{array}{l}\text { Scarce } \\
\text { Stable }\end{array}$ & $\begin{array}{l}\text { Scarce } \\
\text { Decrease }\end{array}$ \\
\hline 6 & 5 & 4 & 3 & 2 \\
\hline
\end{tabular}

Fig. 2 shows "Conservation Vulnerability Matrix cum index". $6=$ very low vulnerability, $5=$ low vulnerability, $4=$ moderate vulnerability, $3=$ high vulnerability and $2=$ very high vulnerability

Arunanchal Pradesh (Fig. 1). It has an area of more than 1058 $\mathrm{km}^{2}$ of which $33 \mathrm{~km}^{2}$ is under cultivation. A comparatively smaller area is under settlement and the rest is covered by forests and plantations. Ten percent of the forest is under government control (unclassified forest) and the remaining part is with Apatani individuals/clans/community. The forest of the Valley is categorized as sub-tropical and temperate climate with a huge diversity of flora and fauna providing diverse NTFPs. The climate is humid sub-tropical to temperate with $235 \mathrm{~cm}$ annual rainfall and 1.9 to $28.1^{\circ} \mathrm{C}$ temperature variation (Dollo et al., 2009).

The Valley is inhabited exclusively by an ethnic group, the Apatani, in the villages except some outsiders in the commercial/urban area. Their unique land-use pattern, resource management and culture of conservation have made them a globally significant community (Kumar and Ramakrishna, 1990). Seven major villages that were established many years ago are Hong, Bulla, Hari, Hija, Bamin-Michi, Mudang-Tage and Dutta (Srivastava et al., 2010; Dollo et al., 2009; Pant, 2000) but a recent article puts the number of villages as thirty five (Yakang et al., 2013) which includes some new villages like Biila, Kalung, Lempia, Posumla, Reru, Tajang, etc. Broad landuse pattern for bioresources is in the form of homegarden, bamboo grove, paddy field, and forests. Diverse NTFPs (medicines, eatables, building materials, etc.) grew in all these land parcels.

\section{Methodology}

The study was conducted between August 2014 and October 2015. A reconnaissance survey in the new and old villages of Ziro Valley revealed that the younger generation had only superficial knowledge about NTFPs, their use, commercialization, conservation, etc. as compared to older people and some middle-aged professionals who were directly or indirectly involved in NTFP harvesting and utilization. Therefore, the latter category of informants was targeted to collect information about collection, consumption, conservation, etc. of the most important NTFPs. Rechlin and Varuni (2006) had also observed that younger generations were spending less and less time in the forests and forest based activities had become less important for survival. As is often the case with traditional societies, the older generations had more intimate knowledge of their plantations, the uses of various trees and herbs, and of the hunting trails through clan forests. A lot of traditional knowledge was being forgotten or discarded by younger generations, mainly due to scarce communication between young and old people (DAL, 2009).

Altogether 17 sites, old and new villages, were included in this study. Fourteen villages (Andong-Tage, Bami, Bamin-Michi, Biila, Bolya, Hari, Hija, Hong, Kalung, Lempia, Posumla, Reru, Suliya and Tajang) and one urban centre (Hapoli) were examined through survey. The key informants contacted for semi-structured interview represented five villages (Dutta, Hari, Hong, Kalung and Old Ziro). Since older people were more comfortable interacting in their dialect, local interpreters were engaged for the questionnaire and semi-structured interview. The questionnaire was mainly used for village dwellers whose main profession was farming but a few vendors were also included. The selection of respondents as well as villages were random. The semi-structured interview was done with those who were engaged in professions other than farming. The selection of key informants was based on the information provided by the village dwellers during interaction. The interaction was slow and also limited in terms of productivity as the targeted people were engaged in work during the day and were only available in the evening, able to spare little time from their busy evening schedule. However, 45 village residents and nine experts from the Apatani community were contacted for questionnaire and semi-structured interview, respectively.

Almost all the respondents provided the vernacular name of the NTFPs. A taxonomist (Dr. P. Gajurel, NERIST, Nirjuli, Arunanchal Pradesh) was consulted for scientific identification of these species. Based on this interaction it was found out that very little work had been done on the taxonomy of plants in the Apatani area or Ziro Valley. Inconsistencies were noticed in the transcription of Apatani names by the various respondentsinterviewees, interviewer and interpreters. This was a result of the absence of a standardized written script for the Apatani language. In order to counter the inconsistencies in transcription a recently published Apatani language dictionary in the Roman script was consulted. However, some of the vernacular names were converted to scientific names using the literature (DAL, 2009; Srivastava et al., 2010; Yakang et al., 2013) and by contacting the local Forest Officers (Rinya K. And Tachang N.) and the Chairman, Biodiversity Management Committees of Ziro Valley (Hibu Tatu, Mudang Challyang and Taru Palo).

While assessing the availability status of the same NTFP in Ziro Valley,the respondents gave different opinions. Based on this qualitative assessment (solely perception of the respondents) 
446

they could be divided into Abundant, Limited and Scarce categories. It was perceived by the author during the interaction that the villager's assessment was based on the availability of the NTFPs in their area (community forest or home gardens) not the whole Valley. Therefore, these assessments were quantified into 3, 2 and 1, respectively. The values were averaged out and rounded off to find out actual category of availability status of a particular NTFP (for e.g. $>2.5$ was Abundant, $>1.5$ to $<2.5$ was Limited and $=$ or $<1.5$ was Scarce). A similar method was adopted for the availability trend with respect to the past 10-15 years, and they were classified in the following categories: Increase, Stable and Decrease. Since availability status and availability trend both influenced the priority of conservation of a species, a "Vulnerability Index" was developed by combining these two parameters into nine different sets and giving them total scores (e.g. $3+3=6$ to Abundant-Increase; $1+1=2$ to ScarceDecrease). These sets were further grouped on the basis of total scores: $6,5,4,3$, and 2 and presented in the form of a matrix as depicted in Fig. 2.

\section{Results and Discussion}

The questionnaire survey revealed that $96 \%$ of the respondents were using NTFPs produced in Ziro Valley. Information from some of the key informants and village elders (Gaonburas) revealed that NTFPs grew in and were collected from kitchen gardens, Bamboo (Bije) groves, bunds of paddy fields (Lengo Aji and Ado Aji), homegardens (Yorlu), and individual/clan/village/community forests (Morey). These parcels of land were found in an almost definite pattern with reference to the settlement (Fig. 3) and at a tentative distance (pers. comm. Tasso Sira). While kitchen gardens were currently maintained for growing mostly exotic vegetables and fruits, barring a few indigenous species, community forests were the main source of indigenous NTFPs. Altogether 112 products of non-timber nature were reported to be used by the Apatani community for different purposes like food supplement, medicine, house construction materials, etc. (Table 1). Many other NTFPs used by them during social customs and rituals were excluded from the text except of those with high emphasis. However, out of all the prioritized NTFP species only 89 could be identified with scientific names. They were of different categories like food plants, medicinal plants, construction material yielding plants and others. Some of them were found common in earlier reported researches like Yakang et al. (2013) where 61 common traditional species were used by Apatani. Also Srivastava et al. (2010) declaired 33 species of indigenous biodiversity from Apatani plateau and last but not the least Kala (2005) found 27 ethnomedicinal plants of the Apatani. Literature review also suggested that these species were distributed beyond Ziro Valley, even in the same (Subansiri) or more districts (Changlang, Dibang, Kameng, Lohit, Siang, Tawang, Tirap) of Arunanchal Preadesh (BSI, 1996; 2008; 2009) and some of them were used by other tribes for food or medicinal purposes (Kagyung et al., 2010; Rethy et al., 2010; Doley et al., 2015). These plants were classified among Dicotyledons (Acanthaceae, Aconitaceae, Actinidiaceae, Amaranthaceae, Anacardiaceae, Apiaceae, Araliaceae, Asteraceae, Begoniaceae, Berberdaceae, Brassicaceae, Caprifoliaceae, Cucurbitaceae, Elaeagnaceae, Euphorbiaceae, Fagaceae, Lamiaceae, Lauraceae, Magnoliaceae, Moraceae, Myricaceae,

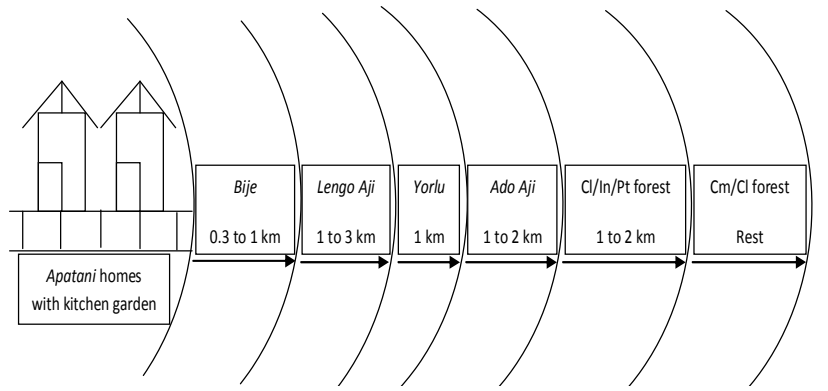

Fig. 3. Land use pattern in Ziro Valley. Cl-Clan, In-Individual, PtPrivate, Cm-Community

Oleaceae, Oxalidaceae, Piperaceae, Plantaginaceae, Poligonaceae, Rhamnaceae, Rosaceae, Rubiaceae, Rutaceae, Saururaceae, Solanaceae, Symplocaceae, Theaceae, Urticaceae, Verbenaceae), Monocot (Arecaceae, Dioscoreaceae, Poaceae, Liliaceae), Gymnosperm (Pinaceae, Taxaceae) and Pteridophyte (Athyriaceae, Gleichaniaceae) families. Kala (2005) working on ethnomedicinal plants of Apatani also reported some of these as dominant families of medicinal plants (Acanthaceae,Asteraceae, Lamiaceae, Rosaceae, Rutaceae, Solanaceae, Urticaceae, and Verbenaceae). Other dominant families in the same area reported by Yakang (2015) are Lauraceae, Magnoliaceae, Rubiaceae, Poaceae, Aeraceae etc.

\section{Priority NTFPs}

The staple food of the Apatani was rice and fish produced in the Valley which was supplemented by wild fruits and vegetables. Wild plant materials were used for health care. Traditional homes were also constructed by materials produced in the community/clan/individual forests and homegardens. The Apatani tribe used a large number of wild NTFPs to meet their diverse requirement and this was possible largely due to the prevalence of a diversity of vegetation in that area (Katewa, 2003). Priority-NTFPs used and identified by them during the present study were 61 species of food supplement, 27 species of medicine, 15 species of construction materials and 9 species of other uses (Table 1). However, all the priority NTFPs identified during the present study were coming either from the forests or homegardens for consumption of the products by the producers directly in the form of green fruits/vegetables /other plant parts or semi-processed/dry form after storage. They were also sold in the market in both fresh and dry form for the consumption of non-producers. Details of the flow of the NTFPs like, production and collection, and disposal through sale are presented in Fig. 4. It was apparent that majority of the products were collected from the forests as compared to home gardens. It was also evident that large number of products was consumed fresh probably day by day. This indicated that the Apatani managed their forests and homegardens aiming directly at NTFP collection and indirectly achieving environmental functions like carbon storage, nutrient cycling, erosion control and hydrological regulation (Myers, 1988; Gillis, 1992).

In Ziro Valley, more than 270 NTFPs of plant origins, mostly wild, have been recorded earlier by different researches (Kala, 2005; Srivastava et al., 2010; Yakang et al., 2013). However, priority NTFPs identified for the purpose of food supplement, medicine, house construction material and few others during this study stood at only 112 , which is much lower in number. These plants were frequently used by the Valley people because of their low cost and local availability. In addition 
Table 1: Priority Non Timber Forest Products with vernacular and scientific names, and major use categories.

\begin{tabular}{|c|c|c|c|}
\hline No & Vernacular name* & Scientific name & Category \\
\hline 1 & Antiitariayi (Entiitariayi, Antriayi) & Actinidiacallosa & Food supplement(Wild Kiwi, fruits eaten raw) \\
\hline 2 & Bachingayi (Bachin ayi) & Myrica esculenta & Food supplement (Fruits eaten raw) / Medicine \\
\hline 3 & Biiling & Choerospondias axillaris & Food supplement(Fruits eaten raw) \\
\hline 4 & Bije & Phyllostachys bambusoides or P. manii etc. & Construction material (Mainly in house construction) \\
\hline 5 & Byako(Puro\& Ami) & $\begin{array}{l}\text { Solanummyriacanthum, } \\
\text { S. kurzi }\end{array}$ & Food supplement (Fruits used as vegetable) \\
\hline 6 & Bуари & Phyllostachysmanii & Food supplement (youngbamboo shoot eaten) \\
\hline 7 & Byukbu & Begonia roxburghii & Other (Tuber used with Rubia manjith produce dye) \\
\hline 8 & Enging(Engin) & Dioscorea hamiltonii & Food supplement (Edible tuber) \\
\hline 9 & Gendahaman (Halyan haman) & Crassocephahum crepidioides & Food supplement (Vegetable) \\
\hline 10 & Giyanghamang (Giyan haman) & Brassica juncea var.rugosa & Food supplement (Vegetable) \\
\hline 11 & Ginseng $^{* *}$ & Panaxpseudoginseng & Medicine(Plant extract) \\
\hline 12 & Hariayi & Elaiagnuslatifolia & Food supplement(Fruits eaten raw) \\
\hline 13 & Harkhuayi & Actinidiachinensis & Food supplement (Juicy edible fruits) \\
\hline 14 & Henchi & Rubusniveus & Food supplement(Fruits eaten raw) \\
\hline 15 & Hiibyo hamang & Hydrocotylejavanica & Food supplement (Leaves as vegetable) \\
\hline 16 & Hiibyolima & Hydrocotylejavanica & Medicine (Medicinal roots) \\
\hline 17 & $\begin{array}{l}\text { Hiiguhamang } \\
\text { (Huguhaman) }\end{array}$ & Oenanthejavanica & Food supplement/Medicinal (Vegetable) \\
\hline 18 & Hiikahamang (Hiika) & Diplazium esculentum & Food supplement (Vegetable) \\
\hline 19 & Hiipe & Elatostemaplatyphyllum & Food supplement (Vegetable) \\
\hline 20 & Hiipe hamang & Gonostegia hirta & Food supplement (Vegetable) \\
\hline 21 & Hiirohamang & Solanumnigrum & Food supplement(Vegetable) \\
\hline 22 & Imyo (Iimyo) & Aconitumferox & Medicine/Animal poison (Smear used in arrows for hunting) \\
\hline 23 & Imyo (Iimyo) & A. heterophylla & Medicine/Animal poison \\
\hline 24 & Jilingayi/Jilyun & Rubusellipticus & Food supplement (Fruits eaten raw) \\
\hline 25 & Jojuruayi & Cocciniagrandis & Food supplement (Fruits eaten raw) \\
\hline 26 & Kheyi & Cinnamomum verum & Food supplement(Spice) \\
\hline 27 & Kiira & Quercusdealbata & Construction material \\
\hline 28 & Kiiraayi & Castanopsishystrix & Food supplement(Fruit) \\
\hline 29 & Kukulyuhamang (Kukulyolye haman) & Artemisia indica & Medicine (leaf smell inhaling, also eaten as vegetable) \\
\hline 30 & Lam hamang/Payinglamu hamang & Croton roxburghii & Food supplement/Medicine \\
\hline 31 & Lase & Dioscoreabulbifera & Food supplement(Tuber as vegetable) \\
\hline 32 & Lobyo & Circium interpositum & Others (used for local salt making) \\
\hline 33 & Luli(Lulihamang) & Persicaria bartata & Food supplement (Vegetable/fodder) \\
\hline 34 & Mepihamang & Plantagoerosa & Food supplement(Vegetable/fodder) \\
\hline 35 & Miji & Sageretiafiliformis & Medicine(Smoke ofbark and stem) \\
\hline 36 & Ngiilyangkbiiko hamang (Ngiilyangkbiiko) & Centella asiatica & Medicine(Whole plant, also used as vegetable) \\
\hline 37 & Nikhe (Dalcbini*) & Cinnamomumspp. & Medicine (Spice) \\
\hline 38 & Okhuihamang(Okbuyihaman) & Oxaliscomiculata & Medicine (Leaves and stem) \\
\hline 39 & Padiihamang & Cardaminehirsuta & Medicine \\
\hline 40 & Patohamang & Clerodendrum colebrookianum & Food supplement(Vegetable) \\
\hline 41 & Patohamang & Clerodendrum glandulosum & Medicine(Leaves, also used as vegetable) \\
\hline 42 & Payu & Balanophora dioca & Others (Gum used for trapping birds, rats) \\
\hline 43 & Pecha & Pymuspashia & Food supplement/ medicine (Fruits eaten raw) \\
\hline 44 & Pepu & Phragmiteskarka & Construction material \\
\hline 45 & Piirii & Leporsia curnallta & Medicine \\
\hline 46 & Piittaayi (Pitaahi) & Pyruscalleryana & Food supplement (Fruits eaten raw) \\
\hline 47 & Rarubamang (Raru, Rari, Rare) & Piperpedicellatum & Food supplement/Medicine(Vegetable) \\
\hline 48 & Riiko & Gynostemmapedata & Medicine(Dried stem powder) \\
\hline 49 & Sadi (Pine seedlings) & Pinuswallichiana & Other \\
\hline 50 & Saha (Branches of pine) & Pinuswallichiana & Other \\
\hline 51 & Salyo & Magnoliachampaca & $\begin{array}{l}\text { Medicinal /Constructional Material (Fruits eaten raw, timber for } \\
\text { construction) }\end{array}$ \\
\hline 52 & Salyoayi & M. oblonga & $\begin{array}{l}\text { Food supplement (Fruits used to make local "chutney", yields } \\
\text { firewood) }\end{array}$ \\
\hline 53 & Samperayi & Phoebegoalparensis & Food supplement(Fruits used as vegetable) \\
\hline 54 & Saniitero & Zanthoxylum rhesta & Food supplement \\
\hline 55 & Sankhe & Quercusgrifithii & Food supplement (Cooked fruits are eaten) \\
\hline 56 & Sankho (Sankan melyan) & Ligustrum ovalifoliaum & Construction material (Used as fence material) \\
\hline
\end{tabular}


448

57

58

59

60

61

62

63

64

65

66

67

68 Tiiming(Tabu Taker, Taming)

69 Tagginghamang

70 Tajar(Tajer)

71 Takho

72 Takuayi(wild cucumber)

73 Takungayi

74 Tale/Tallehamang

75 Tamen, Taming

76 Tamoayi

77 Tape (Epe) hamang

78 Tapyo

79 Tarko

80 Taroayi

81 Taxus**

82 Tayihamang

83 Tibe

84 Tiire (Tiipe Tiire, Lobyo Tiire)

85 Yabing (Yabingyasi)

86 Yodey

87 Yorkhung(Yorkhum)

88 Yoyo (Yoyu)

89 Yaso (cane)

90 Ayapakhe/ Ayopakhe haman $\equiv$ Ayo tapehamang (Pumpkin)

91 Diiransankhan

$$
\text { Hiibin }
$$

Hillang Tai hamang $\equiv$ Taihamang

Hiilyahamang

Hiipehilya hamang (Type of Hiilya hamang)

Kungayi (Khung)

More Taki (三Payu)

Ngeriipiisa

Niming

100 Pabokormaayi

101 Pachukoyuhamang

102 Pantaiayi(Gourd variety)

103 Phoh(Poh)

104 Pinchusaiayi

105 Pinging

106 Puditaru

107 Pumihaman

108 Riiying/Rubin/Riibing

109 Sanchi

110 Siioenghiika

111 TaibilangSan

112 Tapang
Eurya accuminata, Symplocospaniculata

Zanthoxylum sp

Litsea cubeba

Quercusspp.

Litsea citrata

Pinuswallichiana

Cerasuscerasoides

Houttuynia cordata

Duchesnea indica

Mahonia napaulensis

Rubia cordifolia or R. manjith

Strobilanthes helictus

Neomicrocalamusmanii

Dicranopterislinearis

Cucumissativa

Prunuspersica

Allium tuberosum

Mahonia acanthifolia

Rhuschinensis

Cucurbitamoschata

Cyanthillium cinereum

Phyllanthussp

Ficus auriculata

Taxusbaccata

Amaranthustricolor

Sacharum sp.

Berberis wallichiana

Eremocaulon capitatum

Plectranthrusjaponica

Zanthoxylum armatum

Vibrunumfoetidum

Calamusfloribunda

Unidentified

Unidentified

Unidentified

Unidentified

Unidentified

Unidentified

Unidentified

Unidentified

Unidentified

Unidentified

Unidentified

Unidentified

Unidentified

Unidentified

Unidentified

Unidentified

Unidentified

Unidentified

Unidentified

Unidentified

Unidentified

Unidentified

Unidentified
Others(Leaves used along with Rubia manjith as dye)

Construction material (Stem used for fencing)

Food supplement

Medicine (Ripe fruits eaten, also used as spice)

Construction material/Firewood

Medicine(Fruits used as spice)

Medicine (Resin, firewood)

Food supplement/ Construction material (Fruits used in making chutney, timber used for fencing)

Food supplement/ Medicine (Shoot and leaf eaten as vegetable, eaten raw also)

Food supplement (Fruits eaten raw)

Food supplement (Fruits eaten raw, bark used for obtaining deep yellow dye)

Medicine (roots), Stem used as dye

Food supplement (Youngleaves used as vegetable)

Construction material (generally in roof making)

Construction material (Used in fences)

Food supplement

Food supplement (Fruits eaten raw)

Medicine/ Food supplement (Leaves as salad and tuber as medicine)

Food supplement

Medicine(Fruits eaten raw)

Food supplement

Food supplement (also used in salt making)

Medicine(Antiseptic)

Food supplement (Fruits eaten raw)

Medicine

Food supplement (Leaves and stem used as vegetable)

Construction material

Medicine(Thorns used for tattooing/Bark medicinal)

Medicine(Young shootedible)

Medicine (Leaf juice used for wound)

Medicine (Dried fruits used as medicine, also as spice)

Food supplement (Fruits eaten raw)

Construction material

Food supplement (Fruits and leaves eaten as vegetable)

Other(Gum)

Construction material (Thornybamboo variety)

Food supplement

Food supplement

Food supplement

Food supplement (Fruit)

Other(Gum)

Construction material

Other

Foodsupplement

Food supplement (Leafyvegetable)

Food supplement

Medicine(Wild aromatic grass)

Construction

Others (used for local salt making)

Medicine

Food supplement

Construction material

Food supplement

Food supplement

Other (Wood used as axe handle/tools)

Other

*Names differ from one village to another;

${ }^{* *}$ Non-Apatani names 


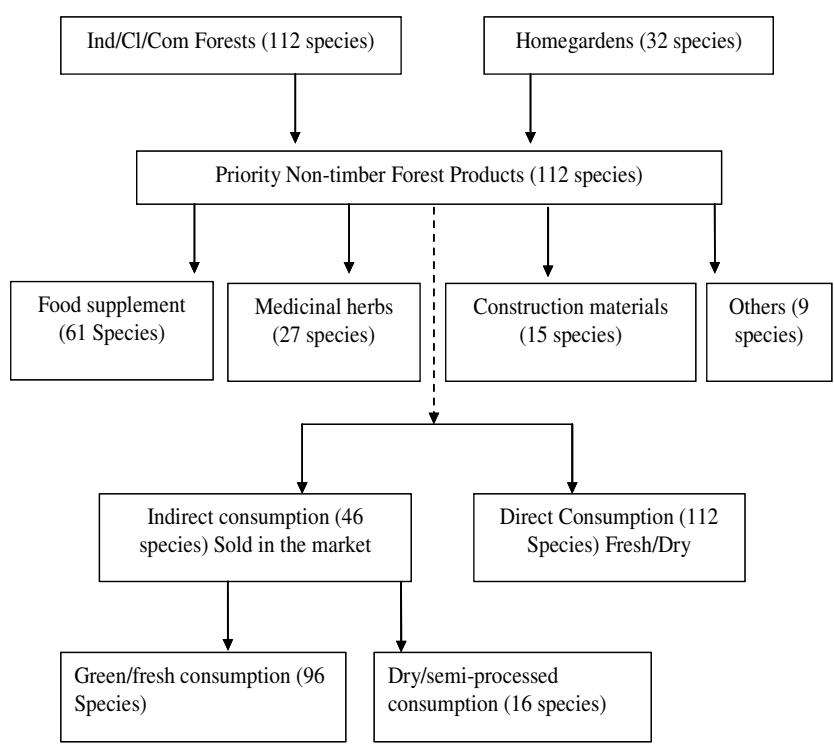

Fig. 4. Production and consumption pattern of Priority NTFPs of Ziro Valley. Ind = individual, $\mathrm{Cl}=$ clan, $\mathrm{Com}=$ community, Forests

to these, the inadequate provision of modern medicine and food alternatives as well as various cultural and religious reasons were also important factors (Shanley and Luz, 2003). A few key informants reported that in the last few decades the use of the NTFPs had multiplied as the selling of the products had increased in the market. This may, in the long run, have a negative impact on sustainable harvesting as opined by Ingram and Bongers (2009). This is to say that when the wild plants move from subsistence use to commercialization, the economic and social livelihoods of harvesters, producers, processors, urban traders and consumers become interlinked through demand and supply interactions that can lead to unsustainable exploitation.

\section{Ecological importance}

Different NTFPs (Table 1) used by the Apatani were mostly produced in their own forests and homegardens. Many NTFPs were also found in reserved (government owned) forests but these were not freely accessible. Although a majority of NTFPs were growing in community forest, as many as 32 NTFPs \{Baching ayi (Myrica esculenta), Bije (Phyllostachys manii), Giyang hamang (Brassica juncea var. rugosa), Hiibyo hamang (Hydrocotyle javanica), Hiilang tai hamang, Hiika hamang (Diplazium esculentum), Jojuru ayi (Coccinia grandis), Kiira (Quercus dealbata), Mepi hamang (Plantago erosa), Miiji (Sageretia filiformis), Ngiilyang khiiko (Centella asiatica), Okbui hamang (Oxalis corniculata), Pachukoyu hamang, Padii hamang (Cardamine hirsuta), Pato haman (Clerodendrum colebrookianum and P. glandulosum), Pantai ayi , Pepu (Phragmites karka), Poh/Phoh, Puditaru, Salyo (Magnolia champaca), Sati (Pinus wallichiana, Resin), Siya hamang (Houttuniya cordata), Subutute (Duchesnea indica), Tale hamang (Allium tuberosum), Tamin (Mabonia napaulensis), Tamo ayi (Rhus chinensis), Tape hamang (Cucurbita moschata), Tarko (Phyllanthus sp.), Tayi hamang (Amaranthus tricolor), Yaso (Calamus floribunda), Yodey (Amaranthus tricolor) and Yorkhum (Zanthoxylum armatum)\} were grown in homegardens for quick access and higher quantity use on a frequent basis. All the NTFP species produced in Ziro Valley were consumed by the Valley dwellers after direct collection and many (46) of them were sold to cater to the need of market dependent people (Table 2). However, some of the commercially important species identified by the key informants were Antiitari ayi (Actinidia callosa) Baching ayi, Biiling (Choerospondias axillaris), Diiransankhan, Hari ayi (Elaiagnus latifolia), Henchi, Hiibyo lima (Hydrocotyle javanica), Hiigu hamang (Oenanthe javanica), Hiipey hamang (Gonostegia hirta), Kung ayi, Ngliyang khiiko, Taro (Ficus auriculata), Padii hamang, Riiko (Ficus auriculata), Siya hamang, Subutute, Salyo ayi (Magnolia champaca, M. oblonga),Samper ayi (Phoebe goalparensis),etc.

However, the respondents could assess 79 ecologically important NTFP species on the basis of availability status and placed 21 species in Abundant, 44 species in Limited and 14 species in Scarce category (Table 3). Similarly, the availability trend of 58 NTFPs was also assessed by them in the following classification-12 species in Increasing, 24 species in Stable and 22 species in Decreasing category. These species, have been evaluated for bot parameters and were grouped according to the "Vulnerability Matrix" (Fig. 2) and presented in Fig. 5. After regrouping, as per the vulnerability index, these species could be categorized as follows: (i) Very low vulnerability: Padii hamang, Sankhe (Quercus griffithii); (ii) Low vulnerability: Bije, Hiigu hamang, Kiira, Kiira ayi (Castanopsis hystrix), Mepi hamang, Sankho (Ligustrum ovalifoliaum), Semo ayi (Cerasus cerasoides), Siya hamang, Byako (Solanum myriacanthum and S. kurzi), Enging (Dioscorea hamiltonii), Lase (Dioscorea bulbifera), Ngerii, Pinchi sai abi, Tamo ayi, Yabin-bije (Cephalostachium capitatum); (iii) Moderate vulnerability: Kukulyu hamang (Artemisia indica), Pachu koyu hamang, Salyo ayi, Sanko ayi (Zanthoxylum sp), Tapang, Baching ayi, Hiipe hamang, Hiika hamang, Pecha (Pyrus pashia), Riiko, Santero (Litsea cubeba), Taaming, Taging hamang (Strobilanthes helictus), Tale hamang, Tamin, Taro ayi, Yorkhum, Bukhe, Pabo kormo ayi, Pumi haman (iv) High vulnerability: Antiitari ayi, Ayapakbe hamang, Biiling, Diiransankhan, Henchi (Rubus niveus), Hiibyo hamang, Ngilyang kbiiko, Raru hamang (Piper pedicellatum), Samper ayi, Santi (Quercus spp.), Tayi hamang, Yaso-cane, Sanchi, Santutaki, Taku ayi (Cucumis sativa) and (v) Very high vulnerability: Hiibin, Imyo (Aconitum ferox and A. heterophylla), Jojuru ayi, Khung, More taku, Payu. The total number of species according to these categories were arranged as per the "vulnerability index" and presented in Fig. 6. Some of these important non-timber products along with others are presented in Fig. 7, Fig. 8 and Fig. 9.

Above NTFPs, along with others, were exploited in the past and their availability status was altered due to harvesting. Currently they were at varying states of vulnerability in terms of need for conservation. This may be due to different intensity of exploitation and methods of extraction and also because of the ability of the species to respond to the extraction. The exploitation of forest resources has a differing effect, depending on the type of species and parts being harvested. Unless harvesting is controlled, some species may become genetically impoverished much more rapidly than others (Arnold and Perez, 2001). Neumann and Hirsch (2000) also concur that large scale harvesting may have ecological effects on NTFPs in the form of negative, positive and even neutral growth. Therefore, looking at the distribution of the species (Fig. 6) it 
Table 2. List of NTFPs sold in the market as food supplement, medicine and construction material

\begin{tabular}{lllll}
\hline SN & Food supplement & Food supplement & Medicine & Construction material \\
\hline 1 & Antiitariayi & Kra ayi & Hibiyo lima & Kiira \\
2 & Bachingayi & Lase & Miji & Riiging \\
3 & Biiling & Padii hamang & Ngilyangkbiiko & Santi \\
4 & Diiransankhan & Pecha & Padiibamang & Sembo \\
5 & Enging & Rare haman & Pecha & \\
6 & Giiyanghamang & Sankhi & Riiko & \\
7 & Hari ayi & Salyo ayi & Santero & \\
8 & Hii/Hiyi & Samperayi & Siya hamang & \\
9 & Henchi & Sanko ayi & Tarko & \\
10 & Hiigu hamang & Siya hamang & Tamin & \\
11 & Hiika hamang & Subutute & Yabingyasi & \\
12 & Hiiro hamang & Takung & Yorkhum & \\
13 & Hiipey hamang & Tape hamang & & \\
14 & Kheyi & Tapyo & & \\
15 & Kungayi & Taro ayi & & \\
\hline
\end{tabular}

Table 3. Category wise list of ecologically important NTFPs based on 10-15 years experience of the respondents

\begin{tabular}{|c|c|c|c|c|c|c|}
\hline \multirow{2}{*}{ No } & \multicolumn{3}{|c|}{ Availability status } & \multicolumn{3}{|c|}{ Availability trend } \\
\hline & Abundant & Limited & Scarce & Increase & Stable & Decrease \\
\hline 1 & Bije & Antiitariayi & Bukhe & Bukhe & Bachingayi & Antiitariayi \\
\hline 2 & Biyapo & Ayapakhe & Hiibin & Byako & Bije & Ayopakhehaman \\
\hline 3 & Вуари & Bachingayi & Imyo & Enging & Hiigu hamang & Biiling \\
\hline 4 & Hiiguhamang & Biiling & Jojuruayi & Lase & Hiipey hamang & Dïransankhan \\
\hline 5 & Kiira & Byako & Khung & Ngerii & Hiikahamang & Henchi \\
\hline 6 & Kitraayi & Dïransankhan & Moretaku & Pabokormoayi & Kiira & Hiibin \\
\hline 7 & Kukulyu & Enging & Pabokormoayi & Padiihamang & Kiiraayi & Hiibyo hamang \\
\hline 8 & Luli & Hariayi & Payinglamu hamang & Pinchisaiabi & Mepihamang & Imyo \\
\hline 9 & Mepihamang & Henchi & Payu & Pumihaman & Pecha & Jojuruayi \\
\hline 10 & Pachukoyu & Hiibyo hamang & Pumihaman & Sankhe & Piita & Khung \\
\hline 11 & Padiihamang & Patohamang & Sanchi & Tamoayi & Riiko & Kukulyu \\
\hline 12 & Piirii & Hiipey hamang & Santotero & Yabin (bije) & Sanchi & Moretaku \\
\hline 13 & Salyoayi & Hiiro & Santutaki & & Sankho & Ngilyangkbiiko \\
\hline 14 & Samo & Hiikahamang & Takuayi & & Santero & Pachukoyu \\
\hline 15 & Sankhe & Kheyi & & & Santutaki & Payu \\
\hline 16 & Sankho & Kungayi & & & Semo & Raruhamang \\
\hline 17 & Sankoayi & Lase & & & Siyahamang & Salyoayi \\
\hline 18 & Semo & Lum hama & & & Taaming & Samperayi \\
\hline 19 & Siyahamang & Ngerii & & & Taginghamang & Sankoayi \\
\hline 20 & Takung & Ngilyangkbiiko & & & Takuayi & Santi \\
\hline 21 & Yodey & Pantariayi & & & Talehamang & Tayihamang \\
\hline 22 & & Pecha & & & Tamin & Yaso (cane) \\
\hline 23 & & Phoh & & & Taroayi & \\
\hline 24 & & Pinchisaiayi & & & Yorkhum & \\
\hline 25 & & Pittaayi & & & & \\
\hline 26 & & Raruhamang & & & & \\
\hline 27 & & Riiko & & & & \\
\hline 28 & & Samperayi & & & & \\
\hline 29 & & Santero & & & & \\
\hline 30 & & Santi & & & & \\
\hline 31 & & Sarlang & & & & \\
\hline 32 & & Subutute & & & & \\
\hline 33 & & Taaming & & & & \\
\hline 34 & & Taginghamang & & & & \\
\hline 35 & & Taihamang & & & & \\
\hline 36 & & Talehamang & & & & \\
\hline 37 & & Tamin & & & & \\
\hline 38 & & Tamoayi & & & & \\
\hline 39 & & Tara & & & & \\
\hline 40 & & Taroayi & & & & \\
\hline 41 & & Yabin (bije) & & & & \\
\hline 42 & & Yaso (cane) & & & & \\
\hline 43 & & Yorkhum & & & & \\
\hline 44 & & Yoyo & & & & \\
\hline
\end{tabular}




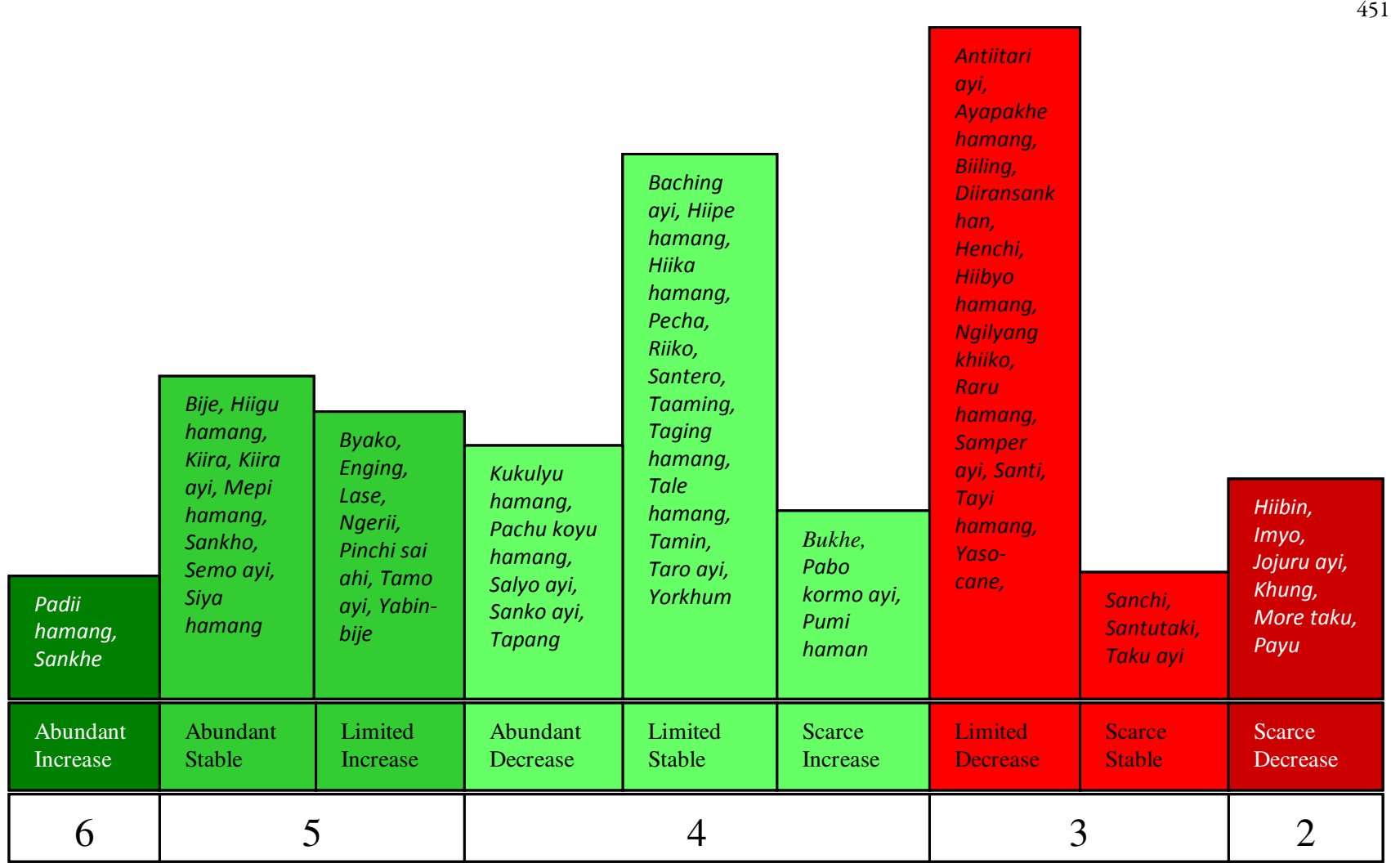

Fig. 5 Group of species as per conservation vulnerability matrix (Abundant-Increase --------> Scarce-Decrease) and index value (6------->2)

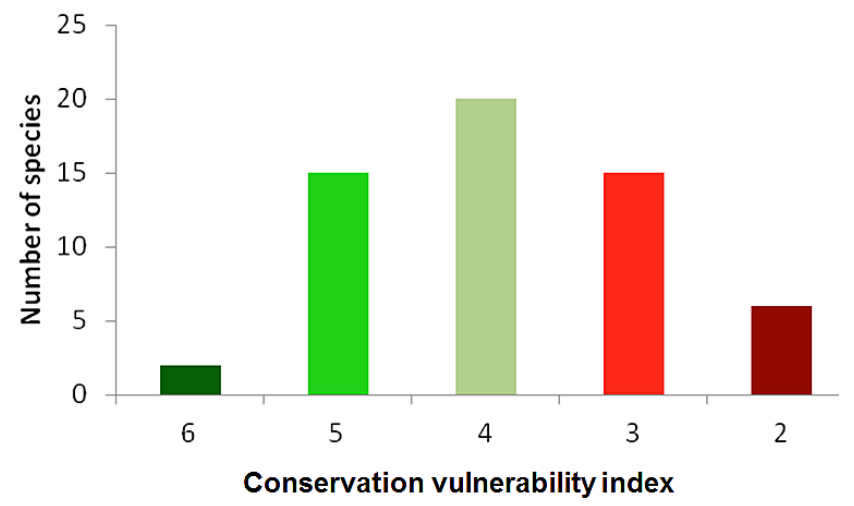

Fig. 6 Species distribution assessed for availability status and availability trend converted to conservation status

could be speculated that with continued exploitation and in the absence of conservation measures this distribution may swing towards vulnerability at least in the case of species in the negative impact category. Currently non-vulnerable species may not be a concern for the villagers but if the NTFP sector is promoted and the demand increases then species-specific management would become critical. The issue of regeneration, cultivation or domestication, sustainable long term supply and harvesting, etc. will need to be addressed simultaneously (Ingram and Tieguhong, 2013).

\section{Conservation need}

The NTFPs classified using the vulnerability index (Table 3 ), need conservation efforts of different levels as they are currently assessed at varying levels of vulnerability. The group of scarcely available plants was Bukhe, Pabo kormo ayi, Payinglamu hamang, Pumi haman, Sanchi, Santotero, Santutaki and Taku ayi. The group of plants which showed decreasing trend of availability was Antiitari ayi, Ayopakhe haman, Biiling, Diiransankhan, Henchi, Hiibyo hamang, Kukulyu, Ngilyang kbiiko, Pachu koyu hamang, Raru hamang, Salyo ayi, Samper ayi, Sanko ayi, Santi, Tayi hamang, Tapang and Yaso-cane. The most important group of plants which had scarce availability status as well as decreasing (availability) trend were Hiibin, Imyo, Jojuru ayi, Khung, More taku and Payu. These needed utmost care so that they could be saved from disappearance from the Valley in the near future.

The economic benefits of NTFP extraction are viable over time only if collection of the species or groups of species is ecologically sustainable. A maximum sustainable harvest limit implies that the rate at which these parts are taken from a plant or at which individual plants are culled from the population will not exceed the natural/artificial rate of regeneration in a given time period (Stanley et al., 2012). Therefore, harvesting without regeneration and the increased marketing of such wild plants may result in decline and reach near-extinction (Ticktin, 2004). Species with great cultural value and economic significance that are at risk of overexploitation and population decline should thus be given top most conservation priority (Hamilton, 2004). Based on their studies on agriculture diversity and conservation of wild plants Norfolk et al. (2013) have advocated that smallholder farms and homegardens can be valuable tools in conservation, preserving local species and maintaining ecosystem functioning.

\section{Sustainability intervention}

The Apatani grew several important species (32) in their homegardens. Some such prominent species were classified on the basis of ecological importance in the following order: Abundant-Increasing: Padii hamang (6); Abundant-Stable: Bije, Kiira, Mepi hamang, Siya hamang (5); Abundant-Decreasing: Pachu koyu hamang, Salyo (4); Limited-Increasing: Tamo ayi 
Table 4. NTFP matrix indicating management options for different NTFPs based on qualitative evaluation by the Ziro Valley residents

\begin{tabular}{|c|c|c|c|c|c|}
\hline Vulnerability status & Ecologically important NTFPs & $\begin{array}{c}\text { Commercially important } \\
\text { NTFPs }\end{array}$ & Domesticated NTFPs & Promotion priority NTFPs & Management option \\
\hline Verylow & Padiihamang, Sankhe & Padiihamang & Padiihamang & Padiihamang & Commercialization \\
\hline Low & $\begin{array}{l}\text { Bije, Hiigu hamang, Kiira, Kirra ayi, } \\
\text { Mepi hamang, Sankho, Semo, Siya } \\
\text { hamang, Byako, Enging, Lase, Ngerii, } \\
\text { Pinchisai abi, Tamoayi, Yabin-bije }\end{array}$ & $\begin{array}{l}\text { Siya hamang, Hiigu } \\
\text { hamang }\end{array}$ & $\begin{array}{l}\text { Siya hamang, Mepi } \\
\text { hamang, Bije, Tamo ayis } \\
\text { Kiira, }\end{array}$ & $\begin{array}{l}\text { Siya hamang, Mepi hamang, } \\
\text { Hiigu hamang, Kirraayis }\end{array}$ & \\
\hline Moderate & $\begin{array}{l}\text { Kukulyu, Pachu koyu Salyo ayi Sanko } \\
\text { ayi, Bachingayi, Hiipey hamang, Hiika } \\
\text { hamang, Pecha, Riiko, Santero, } \\
\text { Taaming, Taging hamang, Tale } \\
\text { hamang, Tamin, Taro ayi, Yorkhum } \\
\text { Bukhe, Pabo kormoayi Pumi haman }\end{array}$ & $\begin{array}{l}\text { Salyo ayi Hiipey hamang, } \\
\text { Bachingayi Riiko, } \\
\text { Kung ayi Biiling, Taro, } \\
\text { Anterayi Hari ayi } \\
\text { Subutute, Hiibyolima }\end{array}$ & $\begin{array}{l}\text { Pachukoyu, Salyo, } \\
\text { Baching, } \\
\text { Hiika hamang, Tale } \\
\text { hamang, Tamin }\end{array}$ & $\begin{array}{l}\text { Hiikahamang, } \\
\text { Bachingayi, Taro, Tamin, } \\
\text { Yorkhum, } \\
\text { Hiiro hamang, Luli hamang, } \\
\text { Pato hamang, Hari ayj Kung, } \\
\text { Pecha, Piita ayi, Hiibyo lima, } \\
\text { Miiji, Riiko, }\end{array}$ & Intermediary \\
\hline High & $\begin{array}{l}\text { Antiitari ayj Ayapakhe hamang, } \\
\text { Biiling, Diiransankhan, Henchi, } \\
\text { Hiibyohamang, Ngilyangkbiiko, Raru } \\
\text { hamang, Samper ayi, Santi, Tai } \\
\text { hamang,Yaso-cane, Sanchi, Santutaki } \\
\text { Takuayi }\end{array}$ & $\begin{array}{l}\text { Dïransankhan, Samper } \\
\text { ayi Henchi, Ngliyang } \\
\text { khiiko, }\end{array}$ & $\begin{array}{l}\text { Tai hamang, Ngiilyang } \\
\text { kbiiko, Hiibyohamang, }\end{array}$ & $\begin{array}{l}\text { Antiitari ayis Rare hamang, } \\
\text { Dirransankhan }\end{array}$ & Conservation \\
\hline Veryhigh & $\begin{array}{l}\text { Hiibin, Imyo, Jojuru ayi Khung, More } \\
\text { taku, Payu }\end{array}$ & & Jojuruayi & & \\
\hline
\end{tabular}

(5); Limited-Stable: Baching ayi, Hiika hamang, Tale hamang, Tamin (4); Limited-Decreasing: Hiibyo hamang, Ngiilyang kbiiko, Tayi hamang (3); Scarce-Decreasing: Jojuru ayi (2). Other homegarden species were categorized into the Limited category (Pato hamang, Poh/Phoh, Subutute) because their availability trend was not indicated by the respondents. There were some more species of homegarden origin (Giyang hamang, Hiilang tai hamang, Miji, Okbui, Pantai ayi, Pepu, Puditaru, Sati (Resin), Tape hamang, Tarko, etc.) whose availability status or trend was not perceived during survey.

Plant species with local importance and multiple functions have been maintained in traditional homegardens in North-East of India as part of survival over generations with a complex vegetation structure (Tangjang and Arunachalam, 2009). The species grown in homegardens were meant for bulk production and also for reducing the pressure on the community forest. This could be construed as management intervention aimed at keeping the community forest resources as the growing reserve. The productivity could be enhanced further by combining the ecological experience of the villagers with scientific knowledge. An additional benefit of this system was its contribution towards ex situ conservation of local plant diversity serving as gene pools of eroding indigenous plant species (Das and Das, 2005; Tangjang and Arunachalam, 2009). Agbogidi and Adolor (2013) have also reviewed the importance of homegardens as conservation units which contain the highest population of some underutilized fruit species. They are in situ conservation sites for indigenous varieties of crops. They are also sites for the domestication of wild varieties of some species. They can be used as trial sites for new varieties of some crops and hence can be considered as an entry point for new varieties of crops into the conservation system.

Recently, some community forest areas have been declared as community reserves as part of a government initiative and are managed by the villagers in order to achieve conservation of medicinal plants growing in them. This is one of the measures to protect and harvest NTFPs on a sustainable basis as suggested by
Manuel (2005). One such initiative in the Ziro Valley is Medicinal Plant Conservation Area, Harkhe Tari of 200 ha established in 2012. This is intended to conserve very important medicinal plants like, Panax pseudo-ginseng, Paris polyfolia, Cinnamomum tamala, C. zeylanicum, Embelia ribes, Berberis aristata and Rubia manjith.

Based on the perception of local stakeholders about the categories of NTFPs a matrix was prepared and presented in Table 4. There are some species (Padii hamang, Sankhe, Bije, Hiigu hamang, Kiira, Kiira ayi, Mepi hamang, Sankho, Semo ayi, Siya hamang, Byako, Enging, Lase, Ngerii, Pinchi sai abi, Tamo ayi and Yabin-bije) which can be commercialized since their conservation need/priority is very low or low. Out of these Padii hamang, Mepi hamang, Higu hamang, Siya hamang, and Kiira ayi are the priority choice to be promoted on a commercial scale. Further, Padii hamang, Siya hamang, and Hugu hamang are commercially important species and Padii hamang, Bije, Mepi hamang, Siya hamang, Tamo ayi, Kiira have the added advantage of being cultivated in homegardens providing extra security against the negative effects of commercialization. Padii hamang, Siya hamang, Mepi hamang and Hugu hamang can be safely recommended for further enhancing the market potential outside the Apatani Valley.

In contrast, Antiitari ayj Ayapakhe hamang, Biiling, Diiransankham, Henchi, Hiibyo hamang, Ngilyang kbiiko, Raru hamang, Samper ayj, Santi, Tayi hamang, Yaso-cane, Sanchi, Santutaki, Taku ayi, Hiibin, Imyo, Jojuru ayi, Khung, More taku, Payu should be conserved since they have high or very high vulnerability status. Although Antiitari ayi, Rare hamang, Diiransankhan are promotion-priority-choice species, Diiransankhan, Samper ayj Henchi, Ngliyang kbiiko, are commercially important species and Tayi hamang, Ngiilyang kbiiko, Hiibyo hamang, Jojuru ayi are homegarden grown species, they should not be promoted for commercialization based on current status. Nevertheless, Antiitari ayj, Rare hamang, Diiransankhan, 


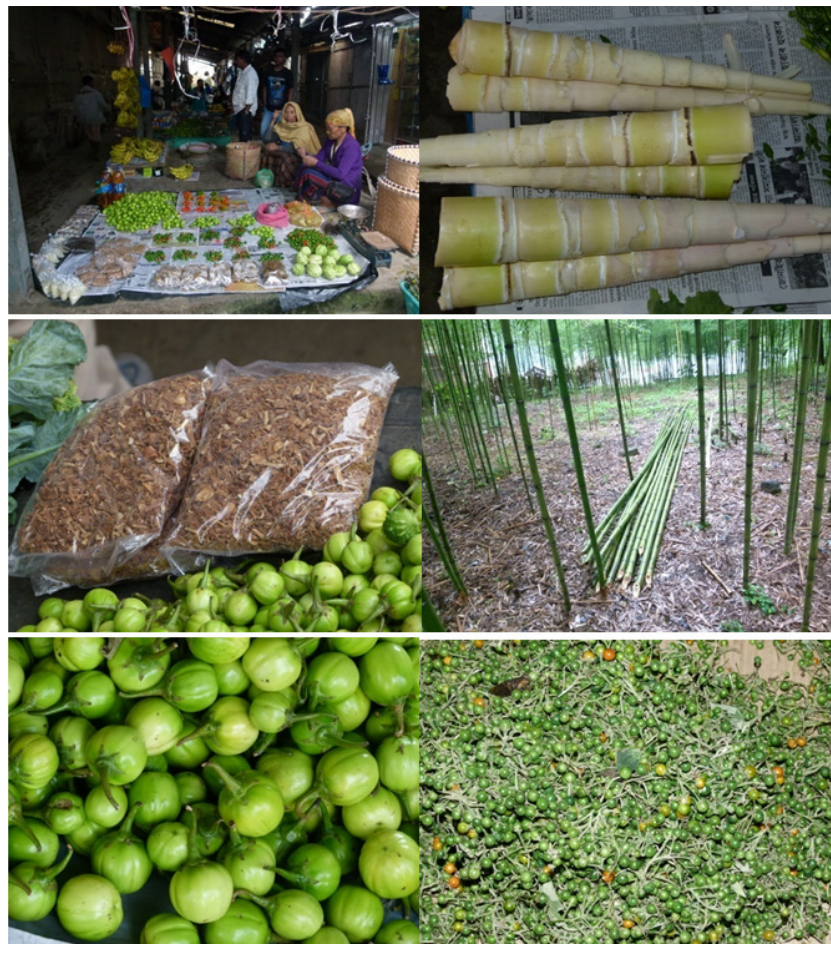

Fig. 7. Local NTFPs used by Apatani. Left to right: first row - Different products in daily market stall and Bamboo shoot; second row - Hiyi and Bije; third row - Byako (Solanum kurzii) and Byako ami (Solanum sp)

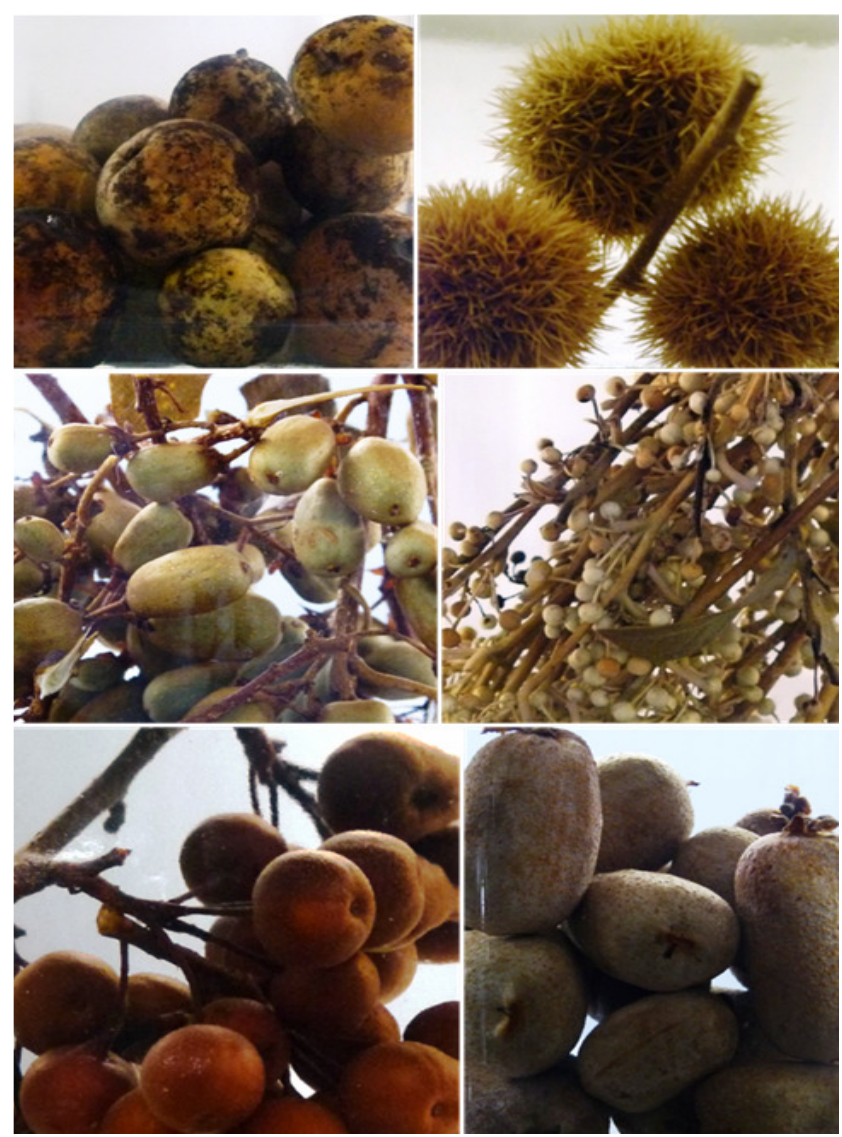

Fig. 9. Local fruits consumed by the Apatani. Left to right: first row - Pecha (Pyrus pashia) and Kiira ayi (Castanopsis hystrix); second row -Harkhu ayi (Actinidia chinensis) and Santero (Litsea cubeba); third row -Pitta ayi (Pymus calleryana) and Antitariayi (Actinidiacallosa).
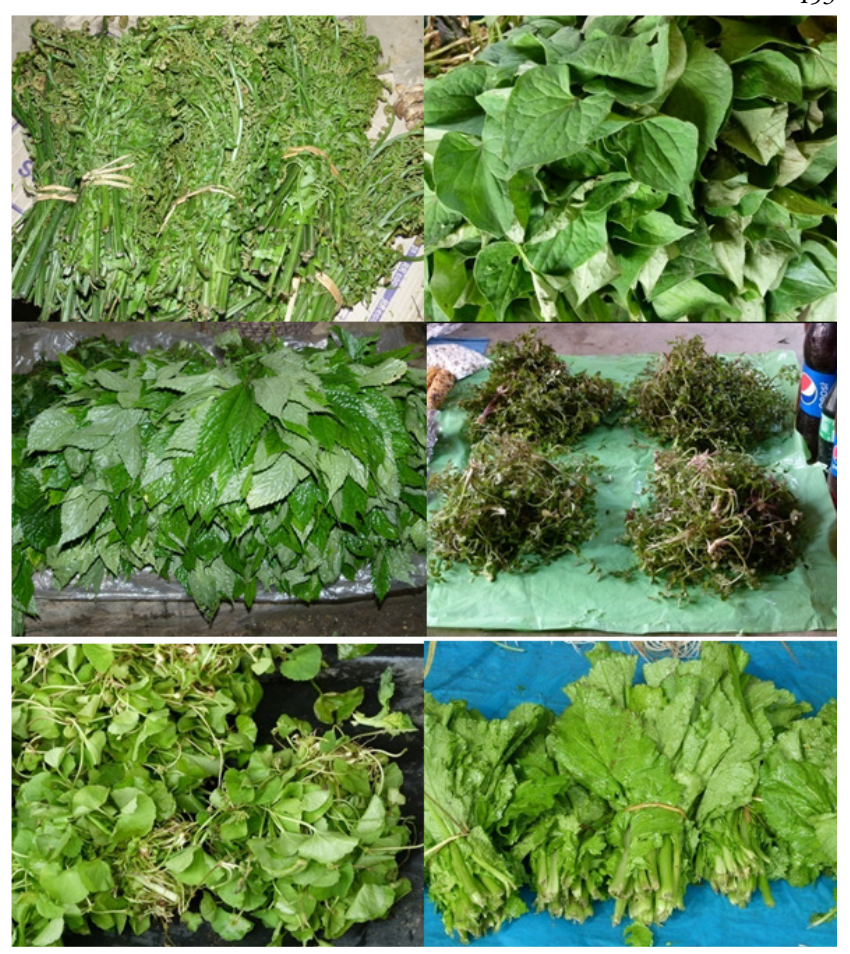

Fig. 8. Leafy NTFP of Ziro Valley. Left to right: first row - Hiika hamang (Diplazium esculentum) and Siya hamang (Houttuynia cordata); second row - Raru hamang (Piperpedicellatum) and Padii hamang (Cardamine hirsuta); third row -Ngliyang Khiko (Centella asiatica) and Giyang hamang (Brassica juncea var.rugosa)

Samper ayi, Henchi, Ngliyang khiiko being commercially important and priority choice species should be managed for recovery first and could be commercialized afterwards.

\section{Conclusions}

There are a lot of host plant species used by the Apatani as NTFPs with plenty of options in the case of medicine and food supplement. They are locally consumed along with a few, edible and medicinal herbs which have marketing potential as well. NTFP utilization had existed for centuries but it has intensified in the past few decades due to an increase in awareness and demand of the products. Increasing demand can lead people to disregard traditional harvesting techniques. The management of NTFPs must not ignore the local indigenous knowledge, the ecological impact of NTFP extraction, the development of appropriate small scale enterprises and cooperatives for collecting, processing, marketing, monitoring and sharing rights and benefits (Uprety et al., 2010).

Natural resources have seen a decrease in availability status and availability trend due to increased exploitation. The increasing demand for natural products in the sectors of food and medicinal ingredients poses major ecological and social challenges. High pressure on wild resources is threatening the survival of populations and species while also endangering local ecosystems. Overharvesting of selected plants for commercialization, premature collection along with habitat destruction, open grazing, forest fire and soil erosion are major threats to the sustainability of NTFP conservation (Famuyide et al., 2013). Unrestrained and unmanaged harvesting is known to have a negative impact on the 
454

structure and dynamics of the population and this can lead to the decline or even disappearance of a plant species (Muraleedharan $e t$ al., 2005; Jimoh et al., 2013; Dattagupta et al., 2014).

Conservation measures are to be taken to ensure sustainability in production and supply. An appropriate policy framework for a sustainable promotion of NTFPs, domestication of NTFPs, improving harvesting, and processing techniques is necessary to facilitate food security, reduction of poverty, and improved livelihoods (Ahenkan and Boon, 2011). Therefore, domestication or homegardening needs to be encouraged. It is widely accepted that the indigenous knowledge is a powerful resource in its own right and complementary to the knowledge available from western scientific sources. By combining the ecological wisdom of the villagers with scientific knowledge higher productivity of homegardens may be achieved without causing substantial environmental degradation (Denevan, 1995; Milate-Mustafa, 2000).

The selection of potential species can be done based on local priority as most of the wild edible species have high nutritional value. Therefore, it seems imperative to carry out studies on the nutritional values of these plants (Angami et al., 2006). Based on the current status of conservation Padii hamang, Siya hamang, Mepi hamang and Hugu hamang is recommendable for marketing. Antiitari ayi, Rare hamang, Diiransankhan, Samper ayi, Henchi, Ngliyang khiiko could also be marketed but only after improvement in their current very low or low conservation status.

The literature survey pointed to gaps in literature, which necessitate further studies to assess the importance of wild plants in the daily life of households, market potential of the wild plants, their contribution to the local people's livelihood (Barirega et al., 2012) and the response to harvesting. It is recommended that future research should focus on gathering detailed information about selected NTFP species, describing habitats, growth requirement, production level and response to harvesting so that a roadmap could be developed for a sustainable management strategy (Ehlers et al., 2003). Simultaneously, a balance needs to be struck between human development and environmental degradation. Further, to address the conflicting demand of commercialization and conservation a comprehensive policy should be adopted (Dattagupta et al., 2014). This should be based on scientific and traditional Apatani knowledge for harvesting and regeneration of NTFPs keeping in mind a minimal impact on the heritage.

\section{Acknowledgements}

The author is thankful to all the people for their unconditional help like Apatani community, Gyati Yam, Diana Angome, Richo, Pubyang, Dr Tripathi, Dr Yadav, IIFM Director, etc.

\section{References}

Agbogidi OM, Adolor EB (2013). Applied home gardens in the maintenance of biological diversity. Science Reports 1 (1):19-25.

Ahenkan A, Boon E (2011). Improving nutrition and health through non-timber forest products in Ghana. Journal of Health Population and Nutrition 29(2):141-148.

Angami A, Gajurel PR, Rethy P, Singh B, Kalita SK (2006). Status and potential of wild edible plants of Arunanchal Pradesh. Indian Journal of Traditional Knowledge 5(4):541-550.
Arnold JEM, Perez MR (2001). Can non-timber forest products match tropical forest conservation and development objectives? Ecological Economics 39:437-447.

Barirega A, Tabuti JRS, Van Damme P, Agea JG, Muwanika V (2012). Potential for commercialization and value chain improvement of wild food and medicinal plants for livelihood enhancement in Uganda. Current Research Journal Biological Sciences 4(2):108-116.

Barua KK, Slowik J (2000). Traditional ecological knowledge and community based sustainable natural resource management in the eastern Himalayas - A case study of the apatani tribe. Retrieved 2015 August 30 from http://www.uni-goettingen.de.

BSI (1996, 2008, 2009). Botanical Survey of India. Materials for the Flora of Arunanchal Pradesh. Vol 1, 2, 3. (Ed). Ministry of Environment and Forests. New Delhi.

DAL (2009). Dictionary of Apatani Language (website). Apatani Language Project ed, Retrieved 2015 August 30 from http://www.apatani-language-society.com

Das T, Das AK (2005). Inventorying plant biodiversity in home gardens: A case study in Barak valley, Assam, Northeast India. Current Science 98:155-163.

Dattagupta S, Gupta A, Ghose M (2014). Diversity of non-timber forest products in Cachar District, Assam, India. Journal of Forestry Reasearh 25(2):463-470.

Denevan WM (1995). Prehistoric agricultural methods as models for sustainability. Advance Plant Pathology 11:21-43.

Doley B, Gajurel PR, Rethy P, Buragohain R (2014). Uses of trees as medicine by the ethnic communities of Arunanchal Pradesh, India. Journal of Medicinal Plant Research 8:857-863.

Dollo M, Samal PK, Sundriyal RC, Kumar K (2009). Environmentally sustainable traditional natural resource management and conservation in Ziro valley, Arunachal Himalaya, India. Journal of American Science 5(5):41-52.

Ehlers T, Berch SM, MacKinnon A (2003). Inventory of non-timber forest product plant and fungal species in the Robson valley. BC Journal of Ecosystem and Management, 4(2):1-15. Retrieved 2015 August 30 from http://www.forrex.org/ jem/2003/ vol4/ no2/ art2.pdf.

Famuyide OO, Adebayo O, Bolaji-Olutunji KA, Awe F, Owoeye AY, Awodele DO, Adeyemo A (2013). Assessment and sustainable management of non-timber forest products used as food and medicine among urban dwellers in Oyo State, Nigeria. Journal of Horticulture and Forestry $5(11): 186-193$.

Furer-Haimendorf C (1980). A Himalayan Tribe: From Cattle to Cash. Berkeley: University of California Press.

Gillis M (1992). Economic policies and tropical deforestation. In: Nepstad, D.C. Schwartzman S. (Eds), Non-timber products from tropical forests: evaluation of a conservation and development strategy. Advances in Economic Botany 9:129-142.

Hamilton AC (2004). Medicinal plants, conservation and livelihoods. Biodiversity Conservation 13(8):1477-1517.

Ingram V, Bongers G (2009). Valuation of Non-Timber Forest Product Chains in the Congo Basin: A methodology for valuation. CIFOR Yaounde, Cameroon, FAO-CIFOR-SNV-World Agroforestry Center-COMIFAC p 80. 
Ingram V, Tieguhong JC (2013). Bars to jars: Bamboo value chain in Cameroon. Ambio 42:320-333.

Jimoh SO, Amusa TO, Azeez IO (2013). Population distribution and threats to sustainable management of selected non-timber forest products in tropical lowland rainforests of south western Nigeria. Journal of Forestry Research 24(1):75-82.

Kala CP (2005). Ethnomedicinal botany of the Apatani in the eastern Himalayan region of India. Journal of Ethnobiology and Ethnomedicine 1:11 doi:10.1186/1746-4269-1-11.

Kagyung R, Gajurel PR, Rethy P, Singh B (2010). Ethnomedicinal plants used for gastro-intestinal diseases by Adi tribes of Dehang-Debang Biosphere Reserve in Arunanchal Pradesh. Indian Journal of Traditional Knowledge 9(3)496-501.

KatewaSS (2003). Contribution of some wild food plants from forestry to the diet of tribal of southern Rajsthan. Indian Forester 129(9):11171131.

Kumar A, Ramakrishnan PS (1990). Energy flow through an Apatani village ecosystem of Aranuchal Pradesh in north-east India. Human Ecology 18:315-336.

Manuel RP (2005). Poverty alleviation and forest conservation: The role of NTFPs. In: Pfund J, Robinson P (Eds). Non-timber forest products between poverty alleviation and market forces, trees and forests in development cooperation pp 8-13.

Milate-Mustafa M, Hall JB, Teklehaimanot Z (2000). Indigenous management techniques in Bangladesh homegardens. International Tree CropJournal 10:215-228.

Muraleedharan PK, Sasidharan N, Kumar BM, Sreenivasan MA, Seethalaksmi KK (2005). Non-timber forest products in the western ghats of India: floristic attributes, extraction and regeneration. Journal of Tropical Forest Science 17(2):243-257.

Norfolk O, Eichhorn MP, Gilbert F (2013). Traditional agricultural gardens conserve wild plants and functional richness in arid South Sinai. Basic and Applied Ecology 14:659-669.

Neumann RP, Hirsch E (2000). Commercialization of non-timber forest products: Review and analysis of research. Center for International Forestry Research Bogor, Indonesia.

Pant R (2000). Apatani valley, Lower Subansiri. CCA/Arunanchal/CS1/Lower Subansiri/apatani/sustainable forest and agriculture management. Retrieved 2015 March 28 from http://www.kalpavriksh.org/images/CCA/Directory/Arunachal_C aseStudy_ApatanivlyLower_Subansiri.pdf.
Rahman M ( 2015). Management of habitat: Change and continuity in Apatani valley. Journal of International Academic Research for Multidisciplinary3(3):119-125.

Rechlin MA, Varuni V (2006). A passion for pine: Forest conservation practices of the Apatani people of Arunachal Pradesh. Himalaya, the Journal of the Association for Nepal and Himalayan Studies 26(1):19-24.

Rethy P, Singh B, Kagyung R, Gajurel PR (2010). Ethnobotanical studies of Dehang-Debang Biosphere Reserve of Arunanchal Pradesh with special reference to Memba tribe. Indian Journal of Traditional Knowledge 9(1):61-67.

Shanley P, Luz L (2003). The impacts of forest degradation on medicinal plant use and implications for health care in Eastern Amazonia. Bioscience 53(6):573-584.

Srivastava RC, Singh RK, Apatani Community, Mukherjee RK (2010). Indigenous biodiversity of Apatani plateau: Learning on biocultural knowledge of Apatani tribe of Arunanchal Pradesh for sustainable livelihoods. Indian Journal of Traditional Knowledge 9(3):432-442.

Tangjang S, Arunachalam A (2009). Role of traditional home garden system in northeast India. Indian Journal of Traditional Knowledge $8(1): 47-50$.

Taylor B (2009). Grounds for democratic hope in Arunachal Pradesh: Emerging civic geographies and the reinvention of gender and tribal identities. In: Sanjib Baruah (Ed), Beyond counter insurgency: Breaking the impasse in northeast India, New Delhi: Oxford University Press pp 308-328.

Ticktin T (2004). The ecological implications of harvesting non timber forest products. Journal of Applied Ecology 41:11-21.

Uprety Y, Boon EK, Poudel RC, Shrestha KK, Rajabhandari S, Ahenkan A, Tiwari NN (2010). Non-timber forest products in Bardiya district of Nepal: Indigenous use, trade and conservation. Journal of Human Ecology 30(3):148-158.

Yakang B (2015). Studies on non timber forest products and associated indigenous knowledge system of Apatanis in Arunanchal Pradesh. $\mathrm{PhD}$ thesis, NERIST, Nirjuli, India.

Yakang B, Gajurel PR, Potsangbam S, Bhuyan LR (2013). Account of common and traditional non-timber forest products used by Apatani tribe of Arunachal Pradesh, India. Pleione 7(2):514-529. 